\title{
Women's Consumption of Probiotic Food; The Example of Yogurt and Kefir
}

\author{
Ebru Gozuyesil $^{1}$ (D), Ayten Arioz Duzgun² (D), Mete Sucu³ ${ }^{(D)}$ \\ ${ }^{1}$ Osmaniye Korkut Ata University, Faculty of Health Sciences, Nursing Department, Osmaniye, Turkey \\ ${ }^{2}$ Ankara Yildirim Beyazit University, Faculty of Health Sciences, Nursing Department Ankara, Turkey \\ ${ }^{3}$ Cukurova University, Faculty of Medicine, Department of Gynecology and Obstetrics, Adana, Turkey
}

Correspondence Author: Ebru Gozuyesil

E-mail: ebrugozuyesil@hotmail.com

Received: 25.01.2018 Accepted: 16.04 .2018

\begin{abstract}
Objective: This study examined the relationship between pregnancy, women's knowledge level, and consumption of probiotic foods.

Methods: This descriptive and cross-sectional study was carried out with the participation of 560 pregnant $(\mathrm{n}: 280)$ and non-pregnant ( $\mathrm{n}: 280)$ women who applied to the Gynecology and Obstetrics polyclinic at a university hospital between June and August 2017. Data were collected using a data collection form developed by the researchers based on relevant scholarly literature.

Results: The two groups (pregnant and non-pregnant women) were similar in average age and educational level. Of the participants, 59.1\% knew the term probiotics. The rates of knowing the term probiotics ( $p: 0.001)$, recognizing kefir as a type of probiotic food, and consuming kefir as a probiotic food ( $p: 0.001$ ) were higher in non-pregnant women than in pregnant women at a statistically significant level $(p<0.01)$. Women consumed probiotic foods mostly for problems in the digestive system (87\%) and strengthening the immune system (74.1\%). Not knowing what probiotic meant was the most common reason (22\%) for not consuming probiotic foods.

Discussion: Of the participants, $59.1 \%$ knew the term probiotics. Non-pregnant women's rate of knowing the term probiotics (67.9\%) was statistically higher than that of the pregnant women (50.4\%) (p: 0.001; $p<0.01$ ). In sum, some pregnant women did not know the term probiotics. In the scholarly literature, there are no studies on pregnant women's consumption and knowledge level of probiotic foods. Most of the studies' sample groups were students. Findings of all these studies show that the most significant reason for not consuming probiotic foods was not having the sufficient knowledge about probiotics. Considering the positive effects of probiotic foods on health, increasing the consumption of probiotics could contribute to a healthy pregnancy. In Turkey, we need to determine pregnant women's knowledge of probiotic foods to initiate and popularize the consumption of probiotics.

Conclusion: Findings of this study indicated that pregnant women did not have sufficient knowledge of the term probiotics. Pregnancy is the ideal period for women to develop behavior that protects and improve both their own and their babies' health. For this reason, raising awareness on and motivating pregnant women toward probiotic food consumption are significant.

Keywords: Pregnancy, probiotics, nutrition
\end{abstract}

\section{INTRODUCTION}

Nutrition is a key element supporting health and growth during the life cycle. Nutritional habits play a crucial role in maintaining a healthy life. A society's health status can be assessed by the presence of healthy individuals. Women's health must be tackled, protected, and improved, primarily because it is closely related to the health status of families and society. Nutrition is significant for individuals from all social levels, but women and children are the most affected groups. Women's healthy nutrition status provides an indicator of the well-being and development of primarily families and society because problems arising from women's health and nutrition are transferred to the next generations through their children $(1,2)$. Although good health requires sufficient and balanced nutrition at all periods of life, pregnancy is one of the special times when the need for proper nutrition increases (1). Good nutrition and healthful life style of the mother during pregnancy is important both for her own and her baby's health. The aim of proper nutrition during pregnancy is to meet physiological needs, keep nutrition supplements in balance, and to provide the energy and nutritional elements necessary for the normal development of the fetus (2).

Probiotics are live microorganisms and/or their constituents that positively affect human health by balancing the intestinal flora. Probiotic products refer to foods that contain added microorganisms presumed to be beneficial for the body; most of the microorganisms used as probiotics are of the lactobacilli group (primarily, Lactobacillus and Bifidobacterium). Other microorganisms are also used as probiotics, S. boulardii among them (3).

Probiotics are added mostly to yogurt and other types of fermented products. Additionally, in the last few years, these bacteria have been added to beverages, turned into tablets, capsules, freeze dried products, and sold in markets $(3,4)$. 
One of the most widely known probiotic food is kefir, which has been produced and consumed for many years by local populations in Caucasia. It is a Turkish traditional fermented milk product obtained through the fermentations of ethyl alcohol and lactic acid using kefir grains. Microorganisms in kefir's structure enable easy digestion, and in this way, increase the absorption of nutritional elements (5).

Another commonly known prebiotic product is yoghurt. Yoghurt is a fermented dairy product that includes prebiotics and has been used by human for centuries. It contains high-quality protein, carbohydrates, and lipids with a high dry matter content and it is also rich in calcium, phosphor, and Vitamin B. Yoghurt provides rich sustenance. It is easy to digest and strengthens the immune system. Yoghurt can also be consumed easily by people with lactose intolerance, so it has an important place in people's lives (4-6).

Probiotic microorganisms have many positive effects on human health. They directly or indirectly affect the intestinal physiology, stimulate the immune system, and influence the host's oral and intestinal digestive system, upper respiratory tract, and mucosal surface of the urogenital system. Therefore, probiotics have a potential health-promoting effect that also decreases the risk for disease (6).

The published literature on the use of probiotic foods during pregnancy showed that probiotic use did not have any effect on the rates of cesarean sections, the week of birth, or birth weight. However, it was observed that some types of probiotics reduced the risk of developing atopic dermatosis in babies, premature birth, and the incidence of bacterial vaginosis. Accordingly, probiotics increased the transmission of some fatty acids to the fetus and cytokines, which signified the positive effects of kefir on the mother's immune system in the milk and blood. Probiotics also decreased the frequency of gestational diabetes in the mother and the level of maternal pre-prandial blood glucose; the scholarly literature did not report any harmful effects of probiotic foods (7-12).

In Turkey, the literature on the use of and the knowledge level of probiotic foods is limited $(4,13,14)$, and there is no study on the use of probiotics during pregnancy. This study analyzed the relationship between pregnancy and women's knowledge level and consumption of probiotic foods.

\section{METHODS}

\subsection{Research Type}

This descriptive study was carried out to determine the relationship between pregnancy and non-pregnant women and the knowledge level and consumption of probiotic foods.

\subsection{Field Site}

The study was carried out at the polyclinics of the Department of Gynecology and Obstetrics of a university hospital, with the participation of pregnant women who applied to the polyclinic and stayed in the maternity ward, and nonpregnant women who stayed at the gynecology clinic.

\subsection{Research Population and Sample}

The research population comprised pregnant and nonpregnant women who applied to the Department of Gynecology and Obstetrics for monitoring and treatment. The number of pregnant women, who applied to the polyclinic monthly between the dates May and June 1, 2017, was 1026. Assuming that a similar number of pregnant women would apply to the same university on a monthly basis, the random sampling method was used; 280 women were included in each of the groups (pregnant and non-pregnant) (n: 560). The two groups were similar in terms of the age range and educational levels. Criteria for women's Inclusion in the study women, who agreed to participate in the study, did not have communication difficulty or mental insufficiency, were pregnant, or not pregnant were included in the study.

\subsection{Data Collection Forms}

Data were collected using a 34-question data collection form, which was developed by the researchers based on relevant scholarly literature $(4,13,14)$. This data collection form was composed of questions to assess pregnant women's sociodemographic and obstetric characteristics, and their use of and knowledge level of probiotic foods.

\subsection{Data Collection}

Researchers collected the data by administering the 34-question data collection form to pregnant and nonpregnant women who applied and stayed at the polyclinic service, using the face-to-face interview technique. Each questionnaire was completed within an average of 8 to 10 minutes.

\subsection{Data Analysis}

IBM SPSS Statistics 22 (IBM SPSS, Turkey) was used for statistical analysis of the data. Descriptive statistical methods (mean, standard deviation, frequency) were employed for quantitative data, whereas the Chi-square test, Yate's Correction for Continuity, and Fisher's Exact Test were used to analyze qualitative data. Significance level was set at $p<0.05$.

\subsection{Research Ethics}

Çukurova University Faculty of Medicine's Ethics Committee, and Çukurova University Balcalı Hospital Department of Gynecology and Obstetrics' Academic Council approved this study. Participants were informed about the aim of this study and were asked to provide written consent using the Informed Consent Form. 


\section{RESULTS}

\subsection{Women's socio-demographic and pregnancy-related characteristics}

In this study, $50 \%(n=280)$ of the women were pregnant and the other $50 \%(n=280)$ non-pregnant; their average age was $29.32 \pm 6.27$ years. Among all participants, $32.7 \%$ were high school graduates. Pregnant women's average pregnancy duration was $27.64 \pm 9.99$ weeks, and the average of number of pregnancies per pregnant woman was $2.55 \pm 1.73$ (Table 1).

Table 1. Women's Socio-demographic and Obstetric Characteristics $(n=560)$

\begin{tabular}{|c|c|c|c|}
\hline Descriptive & $\begin{array}{l}\text { Pregnant } \\
\text { Women }\end{array}$ & $\begin{array}{l}\text { Non-pregnant } \\
\text { Women }\end{array}$ & Total \\
\hline Characteristics & $\begin{array}{l}\text { Mean } \pm \text { SD } \\
\text { Min-Max }\end{array}$ & Mean \pm SD & \\
\hline Age (years) & $\begin{array}{l}29.28 \pm 6.12(18 \\
-44)\end{array}$ & $\begin{array}{l}29.36 \pm 6.42 \\
(18-45)\end{array}$ & $\begin{array}{l}29.32 \pm 6.27 \\
(18-45)\end{array}$ \\
\hline Week of Pregnancy & $\begin{array}{l}27.64 \pm 9.99 \\
(4-41)\end{array}$ & & \\
\hline \multirow[t]{2}{*}{$\begin{array}{l}\text { Number of } \\
\text { Pregnancy }\end{array}$} & $\begin{array}{l}2.55 \pm 1.73(1- \\
13)\end{array}$ & & \\
\hline & n (\%) & n (\%) & n (\%) \\
\hline $\begin{array}{l}\text { Educational Level } \\
\text { Primary school } \\
\text { Secondary school } \\
\text { High school } \\
\text { University }\end{array}$ & $\begin{array}{l}67(23.9) \\
60(21.4) \\
87(31.1) \\
66(23.6)\end{array}$ & $\begin{array}{l}57(20.4) \\
59(21.1) \\
96(34.3) \\
68(24.3)\end{array}$ & $\begin{array}{l}124(22.1) \\
119(21.3) \\
183(32.7) \\
134(23.9)\end{array}$ \\
\hline $\begin{array}{l}\text { Employment Status } \\
\text { Employed } \\
\text { Unemployed }\end{array}$ & $\begin{array}{l}217(77.5) \\
63(22.5)\end{array}$ & $\begin{array}{l}156(55.7) \\
124(44.3)\end{array}$ & $\begin{array}{l}373(66.7) \\
187(33.4)\end{array}$ \\
\hline $\begin{array}{l}\text { Partner's } \\
\text { Educational Level } \\
\text { Primary school } \\
\text { Secondary school } \\
\text { High school } \\
\text { University }\end{array}$ & $\begin{array}{l}52(18.6) \\
62(22.1) \\
89(31.8) \\
77(27.5)\end{array}$ & $\begin{array}{l}28(10.0) \\
38(13.6) \\
107(38.2) \\
107(38.2)\end{array}$ & $\begin{array}{l}80(14.3) \\
100(17.9) \\
196(35.0) \\
184(32.9)\end{array}$ \\
\hline $\begin{array}{l}\text { Perceived Income } \\
\text { Level } \\
\text { High } \\
\text { Middle } \\
\text { Low }\end{array}$ & $\begin{array}{l}85(30.4) \\
184(65.7) \\
11(3.9)\end{array}$ & $\begin{array}{l}89(31.8) \\
176(62.9) \\
15(5.4)\end{array}$ & $\begin{array}{l}174(31.1) \\
360(64.3) \\
26(4.6)\end{array}$ \\
\hline $\begin{array}{l}\text { Place of Residence } \\
\text { City } \\
\text { District } \\
\text { Village-Town }\end{array}$ & $\begin{array}{l}185(66.1) \\
61(21.8) \\
34(12.1)\end{array}$ & $\begin{array}{l}213(76.1) \\
44(15.7) \\
23(8.2)\end{array}$ & $\begin{array}{l}398(71.1) \\
105(18.8) \\
57(10.2)\end{array}$ \\
\hline
\end{tabular}

\subsection{Women's knowledge and consumption of probiotic foods}

Of the participants, $59.1 \%$ knew the term probiotics, and $53.6 \%$ recognized kefir as a probiotic food. It was found that $73 \%$ of the women consumed probiotic food, and $71.6 \%$ consumed yogurt as a type of probiotic. The most commonly cited reason for consuming probiotics was its benefits for the digestive system, at a rate of $87 \%$ (Table 2 ).

The rates of knowing the term probiotics ( $p: 0.001$ ), recognizing kefir as a type of probiotic source ( $p: 0.001)$, and consuming kefir as a probiotic food (p:0.001) were higher in non-pregnant women at a statistically significant level than in pregnant women $(p<0.01)$.

Of the pregnant women, $49.6 \%$ did not consume probiotic food because they "did not know what it was". Looking at the reasons for consuming probiotic food, the rate of health personnel's influence was $15 \%$, whereas the rate of consuming probiotics for the baby's health was $34.3 \%$. These findings for pregnant women were significantly higher than those for the non-pregnant women $(p<0.01)$ (Table 2)

The reasons for non-pregnant women's consumption of probiotic food were strengthening the immune system (33.2\%), easing the problems of constipation (17.3\%), and alleviating existing problems with the digestive system (16.3\%). There was a statistically significant difference between these findings for non-pregnant women and those for pregnant women ( $p<0.01 ; p<0.05$, respectively) (Table 2).

\subsection{Women's knowledge of probiotic food}

Of the participants $71.6 \%$ agreed with the statement "probiotic foods strengthen the immune system"; $72.12 \%$ agreed with the statement "probiotic foods regulate the digestive tract"; $54.8 \%$ agreed with the statement "probiotic foods are helpful in preventing constipation"; $62.7 \%$ agreed with the statement "probiotic foods are beneficial for the baby's health"; and $72.1 \%$ agreed with the statement "probiotic foods protect the body against allergies (eczema)" (Table 3).

Among the women, $48.8 \%$ had no idea about the statement "probiotic foods reduce the risk of cancer"; $58.2 \%$ had no idea about "probiotic foods are helpful in preventing diarrhea"; $51.1 \%$ about the statement "probiotic foods are appetizing", and $50.5 \%$ did not have any idea about the statement "probiotic foods enable the regulation of blood glucose level". 
Table 2. Women's Knowledge Regarding and Consumption Patterns of Probiotic Food

\begin{tabular}{|c|c|c|c|c|}
\hline & $\begin{array}{l}\text { Pregnant Women } \\
(n=280) \\
n(\%)\end{array}$ & $\begin{array}{l}\text { Non-Pregnant } \\
\text { Women }(n=280) \\
n(\%)\end{array}$ & $\begin{array}{l}\text { Total } \\
(n=560) \\
n(\%)\end{array}$ & Significance Level \\
\hline Knowing the Term Probiotic & & & & $x^{2}$ \\
\hline Know & $141(50.4)$ & $190(67.9)$ & $331(59.1)$ & 17.738 \\
\hline Do not know & $139(49.6)$ & $90(32.1)$ & $229(40.9)$ & $\mathrm{p}: 0.001^{* *}$ \\
\hline \multicolumn{5}{|l|}{ Recognizing the Type of Probiotic Food } \\
\hline Yogurt & & & & $x^{2}$ \\
\hline Know & $218(77.9)$ & $232(82.9)$ & $450(80.4)$ & 2.217 \\
\hline Do not know & $62(22.1)$ & $48(17.1)$ & $110(19.6)$ & $\mathrm{p}: 0.136$ \\
\hline Kefir & & & & $x^{2}$ \\
\hline Know & $127(45.4)$ & $173(61.8)$ & $300(53.6)$ & 15.192 \\
\hline Do not know & $153(54.6)$ & $107(38.2)$ & $260(46.4)$ & p:0.001** \\
\hline Consumption of Probiotic Food & & & & $x^{2}$ \\
\hline Yes, I consume probiotic foods. & $207(73.9)$ & $202(72.1)$ & $409(73.0)$ & 0.227 \\
\hline No, I do not consume any probiotic foods. & $73(26.1)$ & $78(27.9)$ & $151(27.0)$ & $\mathrm{p}: 0.634$ \\
\hline \multicolumn{5}{|l|}{ Reasons for not Consuming Probiotic Food } \\
\hline Not knowing what it is & $65(23.2)$ & $(20.7)$ & $123(22.0)$ & \\
\hline Thinking that it is unnatural & $3(1.1)$ & $1(0.4)$ & $4(0.7)$ & $x^{2}$ \\
\hline Not feeling the need to consume & $2(0.7)$ & (6.1) & $19(3.4)$ & 15.280 \\
\hline Finding probiotic food tasteless & $2(0.7)$ & $1(0.7)$ & $4(0.7)$ & p:0.009** \\
\hline Thinking that probiotic foods have no positive effect on health & $2(0.7)$ & $1(0.0)$ & $2(0.4)$ & \\
\hline \multicolumn{5}{|l|}{ Consumed Food Type } \\
\hline Yogurt & & & & $x^{2}$ \\
\hline Yes, I consume yogurt. & $207(73.9)$ & $194(69.3)$ & 401 (71.6) & 1.484 \\
\hline No, I do not consume yogurt. & $73(26.1)$ & $86(30.7)$ & $159(24.8)$ & $\mathrm{p}: 0.223$ \\
\hline Kefir & & & & $x^{2}$ \\
\hline Yes, I consume kefir. & $20(7.1)$ & $72(25.7)$ & $92(16.4)$ & 35.169 \\
\hline No, I do not consume kefir. & $260(92.9)$ & $208(74.3)$ & $468(83.6)$ & $\mathrm{p}: 0.001 * *$ \\
\hline Frequency of Consumption & $(n=207)$ & $(n=202)$ & $(n=409)$ & \\
\hline Once a day & $127(61.4)$ & $120(59.4)$ & $247(60.4)$ & \\
\hline 2-3 times a day & $62(30.0)$ & $44(21.8)$ & $106(25.9)$ & \\
\hline Once a week & $16(7.7)$ & $32(15.8)$ & $48(11.7)$ & 11.729 \\
\hline Once every 15 days & $2(1.0)$ & $6(3.0)$ & $8(1.9)$ & $\mathrm{p}: 0.019^{*}$ \\
\hline Source of Probiotic Food & & & & \\
\hline I make it myself at home. & $161(77.8)$ & $135(66.8)$ & $296(72.4)$ & $x^{2}$ \\
\hline I buy it from the market. & $44(21.3)$ & $67(33.2)$ & $111(27.1)$ & 8.990 \\
\hline Other & $2(1.0)$ & $0(0.0)$ & $2(0.5)$ & p:0.011* \\
\hline \multicolumn{5}{|l|}{ Factors that Affect the Consumption of Probiotic Food ( $n=207)$} \\
\hline Television and the internet & $46(22.2)$ & $56(27.7)$ & $102(24.9)$ & \\
\hline Health Problems & 36 (17.4) & $61(30.2)$ & $97(23.7)$ & \\
\hline Recommendation of friends or immediate surroundings & $47(22.7)$ & $48(23.8)$ & $95(23.2)$ & $x^{2}$ \\
\hline Health Personnel & $31(15.0)$ & $9(4.5)$ & $40(9.8)$ & 24. 310 \\
\hline Probiotic food is natural. & $2(1.0)$ & $1(0.5)$ & $3(0.7)$ & \\
\hline Probiotic food is healthy. & $45(21.7)$ & $27(13.4)$ & $72(17.6)$ & \\
\hline \multicolumn{5}{|l|}{ Reasons for Consuming Probiotic Food ( $n=207$ ) } \\
\hline For Problems Related to the Circulatory System & & & & $X^{2}$ \\
\hline Yes & $15(7.2)$ & $20(9.9)$ & $35(8.6)$ & 0.613 \\
\hline No & $192(92.8)$ & $182(90.1)$ & 37491.4 & p:0.434 \\
\hline For a Constipation Problem & & & & $x^{2}$ \\
\hline Yes & $13(6.3)$ & 35 (17.3) & 48 (11.7) & 11.001 \\
\hline No & $194(93.7)$ & $167(82.7)$ & $361(88.3)$ & $\mathrm{p}: 0.001 * *$ \\
\hline For Strengthening the Immune System & & & & $x^{2}$ \\
\hline Yes & $39(18.8)$ & $67(33.2)$ & $303(74.1)$ & 10.931 \\
\hline No & $168(81.2)$ & 135(66.8) & $106(25.9)$ & $\mathrm{p}: 0.001 * *$ \\
\hline For Problems related to the Digestive System & & & & $x^{2}$ \\
\hline Yes & $20(9.7)$ & $33(16.3)$ & $356(87.0)$ & 42.038 \\
\hline No & $187(90.3)$ & $169(83.7)$ & $53(13.0)$ & p:0.044* \\
\hline For my Baby's Health & & & & $X^{2}$ \\
\hline Yes & $71(34.3)$ & $15(7.4)$ & $86(21.0)$ & 44.463 \\
\hline No & $136(65.7)$ & $187(92.6)$ & $323(79.0)$ & p:0.001** \\
\hline For Overall Health & & & & $x^{2}$ \\
\hline Yes & $142(68.6)$ & $126(62.4)$ & $268(65.5)$ & 1.753 \\
\hline No & $65(31.4)$ & $76(37.6)$ & $141(34.5)$ & p:0.186 \\
\hline \multicolumn{2}{|c|}{$\chi^{2}:$ Chi-square Test, Yate's Correction for Continuity and Fisher's Exact Test } & $p<0.05$ & ${ }^{*} p<0.01$ & \\
\hline
\end{tabular}


Table 3. Women's Knowledge of Probiotic Foods

\begin{tabular}{|c|c|c|c|c|}
\hline Knowledge of Probiotic Foods & $\begin{array}{l}\text { Pregnant } \\
\text { women } \\
(n=280) \\
n(\%)\end{array}$ & $\begin{array}{l}\text { Non-Pregnant } \\
\text { Women } \\
\begin{array}{c}(n=280) \\
n(\%)\end{array}\end{array}$ & $\begin{array}{c}\text { Total } \\
(n=560) \\
n(\%)\end{array}$ & $\begin{array}{c}\text { Significance } \\
\text { Level }\end{array}$ \\
\hline $\begin{array}{l}\text { Probiotic foods strengthen the immune system. } \\
\text { Agree } \\
\text { Disagree } \\
\text { No Idea }\end{array}$ & $\begin{array}{l}200(71.4) \\
9(3.2) \\
71(25.4)\end{array}$ & $\begin{array}{l}201(71.8) \\
4(1.4) \\
75(26.8)\end{array}$ & $\begin{array}{l}401(71.6) \\
13(2.3) \\
146(26.1)\end{array}$ & $\begin{array}{l}X^{2} \\
2.035 \\
p=0.361\end{array}$ \\
\hline $\begin{array}{l}\text { Probiotic foods regulate the digestive tract. } \\
\text { Agree } \\
\text { Disagree } \\
\text { No Idea }\end{array}$ & $\begin{array}{l}198(35.4) \\
8(1.4) \\
74(26.4)\end{array}$ & $\begin{array}{l}206(73.6) \\
3(1.1) \\
71(25.4)\end{array}$ & $\begin{array}{l}404(72.1) \\
11(2.0) \\
145(25.9)\end{array}$ & $\begin{array}{l}X^{2} \\
2.493 \\
p=0.287\end{array}$ \\
\hline $\begin{array}{l}\text { Probiotic foods reduce the risk of cancer. } \\
\text { Agree } \\
\text { Disagree } \\
\text { No Idea }\end{array}$ & $\begin{array}{l}138(49.6) \\
4(1.4) \\
138(48.9)\end{array}$ & $\begin{array}{l}130(46.8) \\
15(5.4) \\
136(47.9)\end{array}$ & $\begin{array}{l}268(47.9) \\
19(3.4) \\
273(48.8)\end{array}$ & $\begin{array}{l}x^{2} \\
6.594 \\
p=0.037 *\end{array}$ \\
\hline $\begin{array}{l}\text { Probiotic foods are helpful in preventing diarrhea. } \\
\text { Agree } \\
\text { Disagree } \\
\text { No Idea }\end{array}$ & $\begin{array}{l}89(31.8) \\
19(6.8) \\
172(61.4)\end{array}$ & $\begin{array}{l}111(39.6) \\
16(5.7) \\
153(54.6)\end{array}$ & $\begin{array}{l}200(35.7) \\
35(6.3) \\
325(58.0)\end{array}$ & $\begin{array}{l}X^{2} \\
3.788 \\
p=0.150\end{array}$ \\
\hline $\begin{array}{l}\text { Probiotic foods are helpful in preventing constipation. } \\
\text { Agree } \\
\text { Disagree } \\
\text { No Idea }\end{array}$ & $\begin{array}{l}157(56.1) \\
10(3.6) \\
113(40.4)\end{array}$ & $\begin{array}{l}150(53.6) \\
7(2.5) \\
123(43.9)\end{array}$ & $\begin{array}{l}307(54.8) \\
17(3.0) \\
236(42.1)\end{array}$ & $\begin{array}{l}X^{2} \\
1.113 \\
p=0.573\end{array}$ \\
\hline $\begin{array}{l}\text { Probiotic foods prevent the development of microorganisms that cause diseases. } \\
\text { Agree } \\
\text { Disagree } \\
\text { No Idea }\end{array}$ & $\begin{array}{l}135(48.2) \\
15(5.4) \\
130(46.4)\end{array}$ & $\begin{array}{l}135(48.2) \\
6(2.1) \\
139(49.6)\end{array}$ & $\begin{array}{l}270(48.2) \\
21(3.8) \\
269(48.0)\end{array}$ & $\begin{array}{l}X^{2} \\
4.158 \\
p=0.125\end{array}$ \\
\hline $\begin{array}{l}\text { Probiotic foods are appetizing. } \\
\text { Agree } \\
\text { Disagree } \\
\text { No Idea }\end{array}$ & $\begin{array}{l}109(38.9) \\
26(9.3) \\
145(51.8)\end{array}$ & $\begin{array}{l}80(28.6) \\
59(21.1) \\
141(50.4)\end{array}$ & $\begin{array}{c}189(33.8) \\
85(15.2) \\
286(51.1)\end{array}$ & $\begin{array}{l}X^{2} \\
17.317 \\
p=0.001 * *\end{array}$ \\
\hline $\begin{array}{l}\text { Probiotic foods are beneficial for the baby's health } \\
\text { Agree } \\
\text { Disagree } \\
\text { No Idea }\end{array}$ & $\begin{array}{l}185(66.1) \\
4(1.4) \\
91(32.5)\end{array}$ & $\begin{array}{l}166(59.9) \\
8(2.9) \\
106(37.9)\end{array}$ & $\begin{array}{l}351(62.7) \\
12(2.1) \\
197(35.2)\end{array}$ & $\begin{array}{l}X^{2} \\
4.618 \\
p=0.202\end{array}$ \\
\hline $\begin{array}{l}\text { Probiotic foods enable the regulation of blood glucose level. } \\
\text { Agree } \\
\text { Disagree } \\
\text { No Idea }\end{array}$ & $\begin{array}{l}127(45.4) \\
4(1.4) \\
149(53.2)\end{array}$ & $\begin{array}{l}136(48.6) \\
10(3.6) \\
134(47.9)\end{array}$ & $\begin{array}{l}263(47.0) \\
14(2.5) \\
283(50.5)\end{array}$ & $\begin{array}{l}X^{2} \\
3.674 \\
p=0.159\end{array}$ \\
\hline $\begin{array}{l}\text { Probiotic foods protect the body against allergies (eczema). } \\
\text { Agree } \\
\text { Disagree } \\
\text { No Idea }\end{array}$ & $\begin{array}{l}99(35.4) \\
14(5.0) \\
167(59.6)\end{array}$ & $\begin{array}{l}101(36.1) \\
9(3.2) \\
170(60.7)\end{array}$ & $\begin{array}{l}200(72.1) \\
23(4.1) \\
337(60.2)\end{array}$ & $\begin{array}{l}X^{2} \\
1.134 \\
p=0.567\end{array}$ \\
\hline
\end{tabular}




\section{DISCUSSION}

The participating groups had similar characteristics: there were no statistically significant differences between participants (pregnant and non-pregnant women) in terms of their ages, duration of marriage, perceived economic status, and educational levels ( $p>0.05$ ) (Table 1).

Of the participants, $59.1 \%$ knew the term probiotics (Table 2). Non-pregnant women's rate of knowing the term probiotics (67.9\%) was statistically higher than that of the pregnant women $(50.4 \%)$ ( $\mathrm{p}: 0.001 ; \mathrm{p}<0.01)$. In sum, some pregnant women did not know the term probiotics. In the scholarly literature, there are no studies on pregnant women's consumption and knowledge level of probiotic foods. Most of the studies' sample groups were students (14-16). Findings of all these studies show that the most significant reason for not consuming probiotic foods was not having the sufficient knowledge about probiotics. Considering the positive effects of probiotic foods on health, increasing the consumption of probiotics could contribute to a healthy pregnancy. In Turkey, we need to determine pregnant women's knowledge of probiotic foods to initiate and popularize the consumption of probiotics.

Although non-pregnant women's rate of recognizing kefir as a type of probiotic food was $61.8 \%$, this rate was only $45.4 \%$ for pregnant women (Table 2), illustrating that pregnant women did not have the sufficient knowledge of kefir to recognize it as a type of probiotic food. Women need to be better informed during pregnancy, a period that present an opportunity to strengthen the health of the fetus.

Among the pregnant women, $73.9 \%$ consumed yogurt, which is known to be the best probiotic food. The study by Zeren (2015) reported that $71.4 \%$ of the participants consumed yogurt, which is among the commonly preferred traditional foods in Turkish cuisine (17). In Turkey, yogurt is widely consumed due to the belief that it is both good for the health and helpful in preventing disease. We believe that women in Turkey do not consume yogurt for probiotic purposes: they consume yogurt as a healthy, natural, nutritious, and easily accessible food.

Table 3 displays the analysis of women's views on the effects of probiotic food on human health.

Of the participants, $32.5 \%$ did not have any opinion about the statement "Probiotic foods are beneficial for the baby's health". It is widely known that maternal nutrition during pregnancy is a significant contribution to fetal development. Previous studies have emphasized that probiotics prevented infections by strengthening the mother's health and the lowering rates of premature birth. Probiotics also improved the health of the mother and the baby by reducing the rate of maternal obesity (18-21).

Of the participants, $53.2 \%$ of the pregnant women and $47.9 \%$ of the non-pregnant women did not have any opinion about the statement "Probiotic food enables the regulation of blood glucose level". However, a study of a group of pregnant women highlighted that probiotic consumption during pregnancy lowered the frequency of gestational diabetes mellitus, maternal blood glucose level, and the frequency of preeclampsia $(12,22)$.

Of the participants, $59.6 \%$ of the pregnant women and $60.7 \%$ of the non-pregnant women did not have any opinion about the statement "Probiotic foods protect the body against allergy (eczema)". Previous studies have revealed that use of probiotic during and after pregnancy reduced the development of atopic dermatitis in babies (23-26).

The children of a group of pregnant women who ingested probiotic supplements starting from two months prior to birth and the following 2 months of breastfeeding were protected against eczema for 24 months after birth (27). If such findings are circulated in training or through the media, awareness could be raised on the importance of use of probiotics by pregnant women.

Among the participants in the present study, $40.4 \%$ of the pregnant women and $43.9 \%$ of the non-pregnant women did not have any opinion about the statement "Probiotic foods are helpful in preventing constipation". The scholarly literature reported that the rate of constipation during pregnancy ranged from about $11 \%$ to $38 \%$ (28). However, there are many studies proving that probiotics prevent constipation, a problem frequently encountered during pregnancy (29-31)

Looking at the "Factors Affecting Women's Consumption of Probiotic Foods", the influence of health personnel on consumption of probiotics was minor (9.8\%) (Table 2). The study by Zeren (2015) emphasized that advertisements were the most influential factor that affect adults' consumption of probiotics (17). Other studies noted the great impact of television on probiotic consumption $(15,16,32,33)$. Our finding indicated that the health personnel did not provide pregnant women with effective and sufficiently detailed education on nutrition. Our experiences lead us to believe that routine clinical briefings have provided only limited information to the pregnant women.

This study provided information on small sample groups because it was carried out out at the polyclinics of the Department of Gynecology and Obstetrics of a university hospital in the Adana province. Hence, the study results could not be generalized over the whole society. Therefore, larger-scale studies are required at the national level for better results.

\section{CONCLUSION}

Probiotics play an increasingly important role, both in the health sector overall, and especially for pregnant women. Although there is an increasing number of studies highlighting the positive effects of probiotics on health, our findings determined that only $50.4 \%$ of pregnant women knew what probiotic foods were. The importance of probiotics should be emphasized, and women should be adequately 
informed about this subject. We stipulate that consumption of probiotics would increase along with the awareness level.

Proper nutrition during pregnancy is crucial both for the mother and for the health of the growing fetus. Nutrition is cost effective: it improves the health and prevents diseases in the mother and the baby. Women sometimes may underestimate the importance of this period and be inattentive to their nutrition. Whereas health-seeking behaviors are expected during pregnancy, pregnant women in our study group did not know the necessary information about probiotics and their significant role in nutrition during pregnancy.

Raising the awareness of mothers and exemplary health personnel would enable an understanding of the significance of consuming probiotic foods for a healthy nutrition. In-service training programs on probiotic foods should be organized for all health personnel, especially midwives and nurses who meet pregnant women more frequently in primary health institutions. In this way, knowledge of probiotic foods should be disseminated. Moreover, as in all areas of life, today the media has a great influence on food selection and the field of nutrition. Women should be informed and awareness should be raised through the media about the importance of food for a healthy nutrition to improve maternal and fetal health.

Acknowlegment: The data from this study presented as an oral presentation at The II. International Multicongress, May 04-05, 2018 in Adana/Turkey.

\section{REFERENCES}

[1] İrge E, Timur S, Zincir H, Oltuluoğlu H, Dursun S. Gebelikte beslenmenin değerlendirilmesi. STED 2005; 14(7): 157-160 (Turkish).

[2] Uzdil Z, Özenoğlu A. Gebelikte çeşitli besin öğeleri tüketiminin bebek sağlığı üzerine etkileri. Balikesir Saglik Bil Derg 2015; 4(2): 117-121 (Turkish).

[3] Yılmaz M. Prebiyotik ve Probiyotikler. Güncel Pediatri 2004; 2: 142-145.

[4] Koçak H, Kalkan S. Üniversite öğrencilerinin probiyotik gıda tüketim alışkanlıklarının belirlenmesi-Bahçe Meslek Yüksek Okulu örneği. DBHAD Uluslararası Hakemli Beslenme Araştırmaları Dergisi 2014; 1 (1): 27-37 (Turkish).

[5] Ceyhan N, Alıç H. Bağırsak mikroflorası ve probiyotikler. Türk Bilimsel Derlemeler Dergisi. 2012; 5(1): 107-113 (Turkish).

[6] Alp G, Aslım B. Insan bağırsak sisteminde probiyotik olarak bifidobakterilerin önemi. Anadolu Üniversitesi Bilim ve Teknoloji Dergisi 2009; 10(2): 343-354 (Turkish).

[7] Dugoua JJ, Machado M, Zhu X, Chen X, Koren G, Einarson TR. Probiotic safety in pregnancy: a systematic review and metaanalysis of randomized controlled trials of Lactobacillus, Bifidobacterium and Saccharomyces Spp. J Obstet Gynaecol Can 2009; 31(6): 542-552.

[8] Mills E, Dugoua JJ, Perri D, Koren G. editors. Herbal medicines in pregnancy and lactation: an evidence-based approach. Taylor \& Francis Group, London: UK; 2006. p.325.

[9] Guarino A, Albano F, Ashkenazi S, Gendrel D, Hoekstra $\mathrm{JH}$, Shamir R, Szajewska H. European Society for Pediatric
Gastroenterology, Hepatology, and Nutrition/European Society for Pediatric Infectious Diseases evidence-based guidelines for the management of acute gastroenteritis in children in Europe: Executive Summary. JPGN 2008; 46(5): 619-621.

[10] Thomas DW, Greer FR. Probiotics and prebiotics in pediatrics. Pediatrics 2010; 126(6), 1217-1231.

[11] Floch MH, Walker WA, Madsen K, Sanders ME, Macfarlane GT, Flint HJ, Dieleman LA, Ringel Y, Guandalini S, Kelly C, Brandt, LJ. Recommendations for probiotic use-2011 update. J Clin Gastroenterol 2011; 45: 168-171.

[12] Lindsay KL, Walsh CA, Brennan L, McAuliffe FM. Probiotics in pregnancy and maternal outcomes: a systematic review. J Matern Fetal Neonatal Med 2013; 26(8): 772-778.

[13] Yurttaş $M$, Yılmaz $M$. Sağlık yüksekokulu öğrencilerinin probiyotik ürünler hakkında bilgi düzeylerinin ve tüketim durumunun belirlenmesi. GÜSBD 2017; 6(2): 64-69 (Turkish).

[14] Aydın M, Açıkgöz i, Şimşek B. Isparta Süleyman Demirel Üniversitesi Öğrencilerinin Probiyotik Ürün Tüketimlerinin ve Probiyotik Kavramının Bilinme Düzeyinin Belirlenmesi. GTED 2010; 5 (2): 1-6 (Turkish).

[15] Balkış M. Lise Öğrencilerinin Beslenme Alışkanlıkları, Probiyotik Sütürünleri Tüketim Sıklıkları ve Bilgilerinin Belirlenmesi: Kulu Örneği. Selçuk Üniversitesi Çocuk Gelişimi ve Ev Ekonomisi Anabilim Dalı, Yüksek Lisans Tezi, Konya. 2011 (Turkish).

[16] Yabancı N, Şimşek, I. Üniversite öğrencilerinin probiyotik ürün tüketim durumları. Kor Hek 2007; 6(6): 449-454 (Turkish).

[17] Zeren R. Yetişkin Bireylerin Probiyotik Besinler Hakkında Bilgi Düzeyi ve Tüketim Durumlarının Belirlenmesi. Haliç Üniversitesi Sağlık Bilimleri Enstitüsü Beslenme ve Diyetetik, Yüksek Lisans Tezi, İstanbul. 2015 (Turkish).

[18] Collado MC, Isolauri E, Laitinen K, Salminen S. Distinct composition of gut microbiota during pregnancy in overweight and normal-weight women. Am J Clin Nutr 2008; 88: 894-899.

[19] Cani PD, Amar J, Iglesias MA, Poggi M, Knauf C, Bastelica D, Neyrinck AM, Fava F, Tuohy KM, Chabo C, Waget A, Delmée E, Cousin B, Sulpice T, Chamontin B, Ferrières J, Tanti JF, Gibson GR, Casteilla L, Delzenne NM, Alessi MC, Burcelin R. Metabolic endotoxemia initiates obesity and insulin resistance. Diabetes 2007; 56: 1761-1772.

[20] Myhre R, Brantsæter AL, Myking S, Gjessing HK, Sengpiel V, Meltzer HM, Haugen M, Jacobsson B. Intake of probiotic food and risk of spontaneous preterm delivery. Am J Clin Nutr 2011;93:151-157.

[21] Brantsaeter AL, Myhre R, Haugen M, Myking S, Sengpiel $V$, Magnus $P$, Jacobsson B, Meltzer HM. Intake of probiotic food and risk of preeclampsia in primiparous women: the Norwegian Mother and Child Cohort Study. Am J Epidemiol 2011;174:807-815.

[22] Wickens KL, Barthow CA, Murphy R, Abels PR, Maude RM, Stone PR, Mitchell EA, Stanley TV, Purdie GL, Kang JM, Hood FE, Rowden JL, Barnes PK, Fitzharris PF, Crane J. Early pregnancy probiotic supplementation with Lactobacillus rhamnosus HNO01 may reduce the prevalence of gestational diabetes mellitus: a randomized controlled trial. Br J Nutr 2017; 117: 804-813.

[23] Barthow C, Wickens K, Stanley T, Mitchell EA, Maude R, Abels P, Purdie G, Murphy R, Stone P, Kang J, Hood F, Rowden J, Barnes $P$, Fitzharris P, Craig J, Slykerman RF, Crane J. The Probiotics in Pregnancy Study (PiPStudy): rationale and design of a doubleblind randomised controlled trial to improve maternal health 
during pregnancy and prevent infant eczema and allergy. BMC Pregnancy and Childbirth 2016; 16: 133-143.

[24] Kalliomaki M, Kirjavainen P, Eerola E, Kero P, Salminen S, Isolauri $S$. Distinct patterns of neonatal gut microflora in infants in whom atopy was not developing. J Allergy Clin Immunol 2001; 107: 129-134.

[25] Zuccotti G, Meneghin F, Aceti A, Barone G, Callegari ML, Di Mauro A, Fantini MP, Gori D, Indrio F, Maggio L, Morelli L, Corvaglia L. Probiotics for prevention of atopic diseases in infants: systematic review and meta-analysis. Allergy 2015;70: 1356-1371.

[26] Garcia-Larsen V, Lerodiakonou D, Jarrold K, Cunha S, Chivinge J, Robinson Z, Geoghegan N, Ruparelia A, Devani P, Trivella M, Leonardi-Bee J, Boyle RJ. Diet during pregnancy and infancy and risk of allergic or autoimmune disease: A systematic review and meta-analysis PLOS Medicine 2018; 28: 1-25.

[27] Rautava S, Kainonen E, Salminen S, Isolauri E. Maternal probiotic supplementation during pregnancy and breastfeeding reduces the risk of eczema in the infant. J Allergy Clin Immunol 2012; 130(6): 1355-1360.
[28] Verghese TS, Futaba K, Latthe P. Constipation in pregnancy. TOG 2015; 17: 111-115.

[29] Mirghafourvand M, Rad AH, Mohammad ACS, Fardiazar Z, Shokri K. The effect of probiotic yogurt on constipation in pregnant women: a randomized controlled clinical trial. Iran Red Crescent Med J 2016; 18(11): e39870.

[30] Cullen G, O'Donoghue D. Constipation and pregnancy. Best Pract Res Clin Gastroenterol, 2007; 21(5): 807-818.

[31] Gilmartin CE, Vo-Tran TH, Leung L. Complementary medicines in pregnancy: recommendations and information sources of healthcare professionals in Australia. Int J Clin Pharm. 2018; 40(2):421-427.

[32] Schultz M, Baranchi A, Thurston L, Yu YC, Wang L, Chen J, Sapsford M, Chung J, Binsadiq M, Craig L, Wilkins B, McBride $D$, Herbison P. Consumer demographics and expectations of probiotic therapy in New Zealand: results of a large telephone survey. N Z Med J 2011; 124 (1329): 36-43.

[33] Derin DÖ, Keskin S. Gıda mühendisliği öğrencilerinin probiyotik ürün tüketim durumlarının belirlenmesi: Ege Üniversitesi örneği. Gıda 2013; 38(4): 215-222 (Turkish). 